\title{
A sustainability analysis on the trends and frequency of the channel flow of a carp breeding river against human interventions and governing public-private partnership (PPP) as adaptation
}

\author{
Probal Saha $^{1}$ (1) $\cdot$ Minhazul Islam ${ }^{2} \cdot$ Jarin Tasneem Oyshi ${ }^{3} \cdot$ Roufa Khanum $^{3} \cdot$ Ainun Nishat $^{3}$
}

Received: 23 November 2019 / Accepted: 15 April 2020 / Published online: 25 April 2020

(c) Springer Nature Switzerland AG 2020

\begin{abstract}
This study presents the trends of channel flow against human interventions and proposes an adaptation plan through a public-private Partnership (PPP) model to overcome the existing deteriorating condition of the Halda River. Being the only natural carp breeding ground in Bangladesh, the Halda River is significant for the national economy. However, the river's destiny is now stricken with infrastructural obstructions, industrial and residual usage exploits, and short-sighted interventions, whereas the impacts of climate change are likely to worsen the scenarios with high salinity intrusion. The unplanned human interventions due to agricultural purposes are continuously obstructing the river flow and demolishing the carp habitats and spawning within the Halda River extremely. Most of the river bends are potential carp breeding grounds along the river stretch, and the low river flow during pre-monsoon is also impacting the sustainability of the aquatic eco-system. To understand the issues behind the endangering Halda River, this study conducted a sustainability analysis through the river planform, stage trend, and frequency analyses. The planform analysis showed the encroachment of the river impacting the river bends, significant for aquaculture over the last three decades, whereas the stage trends showed the low availability water scenario in these four locations of the river stretch. Besides, the frequency analysis reviewed the threshold minimum flow for the survival of the aquatic habitat, showing that the flow during the pre-monsoon is unsuitable and unacceptable for the survival of the fish habitats using Gumbel distribution. Conservation of the Halda River is a national priority due to its unique ecological and commercial importance, and it is expected that the proposed PPP framework will ensure the long-term sustainability of the river ecosystem. This article is analysing the existing situation of the Halda River and proposing a joint effort from government and private organisation through the PPP model for sustainable ecosystem management as well as the economic benefits of the country. Working together, each of the stakeholders will find direct benefits and can be instrumental for the survival of the Halda River.
\end{abstract}

Keywords Halda River · Timeseries trend analysis · Channel pattern trend · Frequency analysis · Public-private partnership · sustainability

$\begin{array}{llll}\text { Abbreviations } & \text { ArcSWAT } & \text { Arc Soil and Water Assessment Tool } \\ \text { PPP } & \text { Public-private partnership } & \mathrm{Q}_{75} & \text { 75th percentile of flow } \\ \text { US\$ } & \text { United States dollar currency } & \text { PWD } & \text { Public Works Datum } \\ \text { DO } & \text { Dissolved oxygen } & \text { CN } & \text { Curve number } \\ \text { BWDB } & \text { Bangladesh Water Development Board } & \text { SOL_AWC } & \text { Available water capacity of the soil layer }\end{array}$

$\triangle$ Probal Saha, probal1421@gmail.com; Minhazul Islam, mislam48@students.tntech.edu; Jarin Tasneem Oyshi, jtoyshi@bracu.ac.bd; Roufa Khanum, roufa@bracu.ac.bd; Ainun Nishat, nishat@bracu.ac.bd | ${ }^{1}$ Civil and Environmental Engineering, University of Tennesse, Knoxville, TN 37996, USA. ${ }^{2}$ Civil and Environmental Engineering, Tennessee Technological University, Cookeville, TN 38501, USA. ${ }^{3}$ Centre for Climate Change and Environmental Research (C3ER), BRAC University, Dhaka 1212, Bangladesh. 


$\begin{array}{ll}\text { ESCO } & \text { Soil evaporation compensation factor } \\ \text { cumec } & \text { Cubic metre per second } \\ \text { yr } & \text { Year } \\ \text { WQAA } & \text { Water Quality Accountability Act } \\ \text { DEM } & \text { Digital elevation model }\end{array}$

\section{Introduction}

Conservation of the Halda River is a national priority due to its unique ecological and commercial importance. In this regard, UNDP initiated to conduct three feasibility studies on the Halda River of Bangladesh in association with the Centre for Climate Change and Environmental Research (C3ER), BRAC University. The ultimate and unique objective of the study is to envisage a project to the sustainable water management that addresses the problems of the Halda River ecosystem and its sustainable management.

Halda River is one of the most important tributaries of the River Karnaphuli and is the only natural carp (Cyprinus carpio) breeding site of Bangladesh [1, 2]. Carp fries collected from the river are the only natural breeding supplied to different divisions of Bangladesh for aquaculture. This river possesses a closed aquatic ecosystem that supports various species of plants, fish, and other organisms. Also, egg collection is the primary profession of $30 \%$ of the local community, and only $50 \%$ of them have secondary occupations [3].

All in all, the total economic worth of the resources of the Halda River is estimated at approximately US\$ 20.5 million, which has a significant contribution to the country's economy [4]. However, different human interventions and infrastructures have increased the influence of the river ecosystem in recent years to meet the growing demands of local communities [5]. This situation is also evident in the Halda River ecosystem. Sediment transport along the riverbed influences the river morphology evolution [6]. Dam constructions reduce water level at the downstream, which may negatively impact the ecological integrity of the river ecosystem by river sediment dynamics and morphology as well as water quality and habitat availability of aquatic $[5,7]$. The carp fish territory is under extinction risk because rubber dams, embankments, sluice gates, along with the loop cutting in meanders and waste discharge from paper and power plant industries at the river upstream are obstructing the minimum flow required for the carp habitats and spawning within the Halda River [2].

Besides, industrial dumping, bank erosion, over-extraction of water, high salinity intrusion along with climate change are also questioning the hydrologic sustainability for the aquatic habitat in Halda River [8,9]. High salinity intrusion in the river has already activated and endangered the river conditions [10-12]. This over-extraction of water for irrigation of tea and Boro rice cultivation is not only upsetting the aquatic life but also impacting bank erosion and saline intrusion [3]. All the waste and debris of the large brickfields at the banks of the river directly flow into the river during the high tide changing the chemical equilibrium of the water quality severely [13]. Another responsible factor behind the lowering of water quality in the Halda River is the abrupt water-level rise during monsoon, causes increased flow velocity, severe bank erosion, and drops down the dissolved oxygen (DO), water temperature, and acidic nature of river $[8,9]$. Also, a channel geometry study could facilitate the flow discharge of flood better than the existing channel, thus preventing damages at river bends, which could sustain spawning [14]. Therefore, this study was initiated to understand the current issues responsible for the deterioration of the Halda river and propose a sustainable solution to protect the river ecosystem.

Rapid urbanisation growth and resource constraint are making it difficult for government agencies to provide quality public services. In this regard, the PPP model is gaining popularity in different developed nations, as well as developing ones as this type of models combines the strength of the government organisations as administrators, whereas private sectors as actors with mutual commitments $[15,16]$. Also, the PPP model can play an active role in environmental governance, as public participation plays a supervisory role to a great extent [16]. It is expected that the adaptation of this PPP framework will bring some positive changes to overcome the environmental issues and ensure the long-term sustainability of the Halda River enhanced collaboration between public and private stakeholders with steady development of interactive services and sharing of expenses, risks, and benefits $[17,18]$. A few essential components of strong public-private partnerships include resource obligations, contribution and transparency, capacity development, flexibility, social, and ecological responsibility [19]. The application of public-private partnership as an organisational tool requires dynamic and continuous inspection of the services provided, to assess whether they are appropriately and expertly conducted by the private stakeholders $[20,21]$. A top-down approach is usually seen to fall short in addressing environmental problems as potential climate change impacts of salinity intrusion, sea-level rise, and frequent cyclones, increasing the unsustainability of biodiversity, and unusual discharge of hazardous wastes [10]. The intricacy and uncertainty of these issues have redefined the outdated roles of the private sector, government, and non-governmental stakeholders [22]. Thus, a group of innovative ideas, including cross-sector alliances, voluntary treaties, and evidence-based approaches as public-private partnerships, is crucial to address the 
environmental issues [23]. Public-private partnership of the government as administration and private sectors along with the local community as actors can be an ideal adaptation for the sustainability and protection of the Halda River. This will not only enhance the ecosystem of the Halda River and preserve the carp habitats, but also benefit the stakeholders economically dependent on the river.

The primary objective of the study is to conduct a sustainability analysis to understand the impacts of human interventions on a carp breeding river and develop an adaptation solution. The specific objectives of the study are as follows:

- Conduct the planform analysis over the last three decades to understand the increasing human interventions on the Halda River.

- Conduct the stage trend analyses at different sites throughout the river to assess and identify the low flow river locations.

- A frequency analysis will be conducted to understand the impacts of three dams on the Halda River in lowering the seasonal flow compared to the threshold

- Develop a public-private partnership (PPP) model incorporating the local communities' perspectives and propose an adaptation solution for sustainable river management.

\section{Study area}

Halda River originates from the mountain range of the Chittagong, Bangladesh, and merges into the Karnaphuli River, 22 miles away from the Bay of Bengal [1]. The spatial location of the Halda River in Bangladesh selected for study and visited sites are identified in Fig. $1 a$ and $b$.

A preliminary study area visit was done to assess and observe the Halda River scenarios. A group of members comprising water resources and hydrology experts visited the Halda River during October 2017. Several listed carp breeding locations, industrial areas, sand mining place, and dams were transected, and focus group discussions were conducted to understand the local perspectives. Some adaptation strategies like encouraging the solar boat use instead of fuel engine boat, stop fishing female carp to save the river resources area campaign are already started within the local people. The issues observed from the site visit are listed down in Table 1.

Halda River's destiny is now stricken with obstructions, industrial wastes, and short-sighted interventions. Considering the problems identified by the local community and river authority, four major issues of Halda River are identified and suggested solutions from the local community and stakeholders are discussed briefly in Table 2 .

\section{Methodology}

The methodology of the study is represented using a flow chart in Fig. 2.

\subsection{Data sources}

The river stage data were daily, and the river flow data were monthly data from the BWDB (Bangladesh Water Development Board). The data resolution was selected based on the best available data collected in the region by BWDB, and monthly discharge data were converted to daily using the stage-discharge rating curve. River stage data were used to calibrate the hydrodynamic "Delft 3D" model water level, and the flow data were used to calibrate the hydrologic model "ArcSWAT" [1]. The sources of data collected for the trends and frequency analysis are listed down in Table 3.

\subsection{Planform and trends analysis}

River planform analysis, river stage trend analysis, and frequency analysis will be done in this section to analyse the hydrological alteration in the river reach locations. The historical and present impact of hydrological changes in the river will be examined from the observations. River planform analysis of 1984, 2003, 1989, 2010, and 2014 shows the planform change, widening or narrowing of banks, determination of left or right bank erosion, whereas trend analysis of the four sites in the Halda River helps to assess the identification of dried or filled up portions of the river.

\subsection{Frequency analysis}

Gumbel distribution is used for the frequency analysis of the peak flow of Panchpukuria Station for 1985-2015. Estimated reduce variate will validate the suitability of the expected flow prediction for Halda River. Secondly, the expected extreme flow and flow duration curve will be developed to estimate the expected flow $\left(Q_{75}\right)$ of the river. Finally, the minimum flow analysis of three dams on the Halda river will be assessed for seasonal flow.

\subsection{Public-private partnership model}

A public-private partnership model is proposed with the government organisations as administrators, whereas 


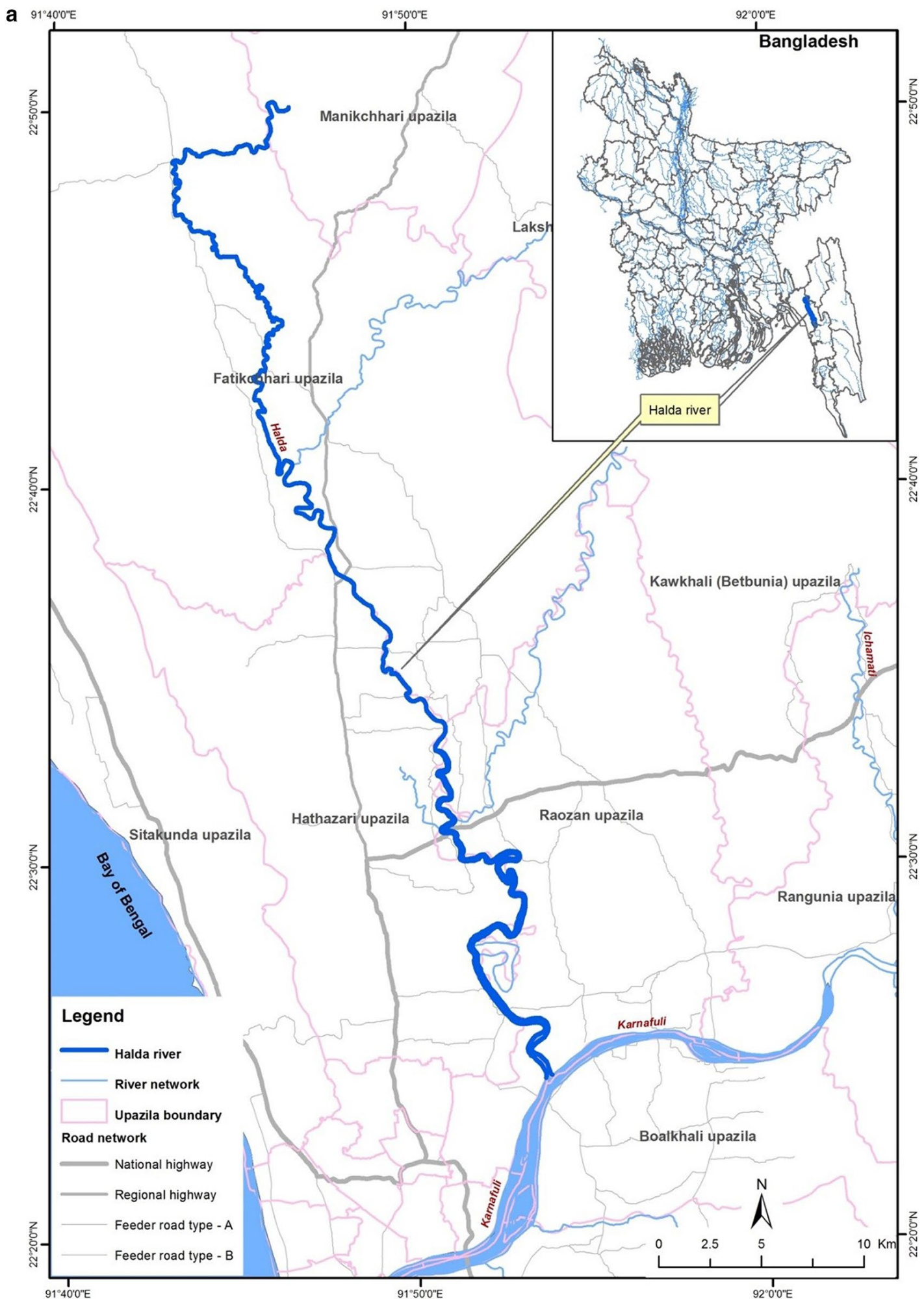

Fig. 1 a Halda river reach of Bangladesh and $\mathbf{b}$ site visit locations

private sectors as actors. The first step is the identification of responsible stakeholders of the Halda River and their role in river sustainability. Based on the financial and administrative roles of the stakeholders, a model will be proposed in the public-private partnership framework as an adaptation strategy for the Halda River. 


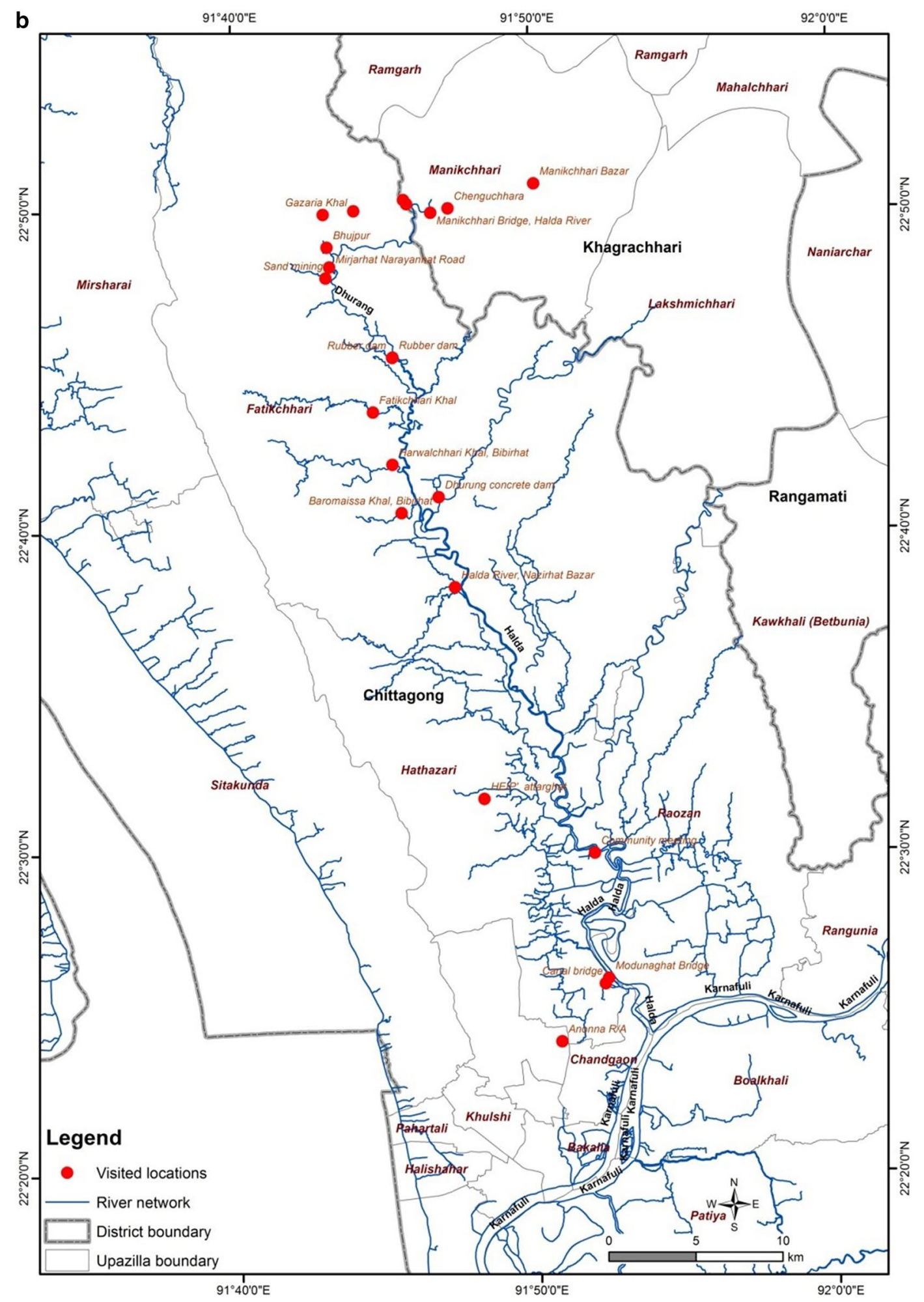

Fig. 1 (continued) 
Table 1 Notable spots visited during the visit

\begin{tabular}{lll}
\hline Locations & Observations & Problems \\
\hline Anonna R/A & Drainage channel & Blackwater and bad smell \\
Fatikchhari Khal & Black shell oyster of saline water observed & Fish eggs production dropped \\
Bhujpur rubber dam & The downstream section found dried up & Reducing flow and fisheries \\
Soilkupa village & Sand mining spot & Dredged areas cause bank collapse \\
Gazaria Sluice Gate & The sluice gate is for irrigation purpose & Interrupts the fish movement \\
Dhurang Dam & Water is extracted and stored for irrigation purpose & Causes drought in the downstream \\
\hline
\end{tabular}

Table 2 Major problems and solutions of Halda River

\begin{tabular}{|c|c|c|}
\hline Problems & Impacts & Solutions \\
\hline $\begin{array}{l}\text { Infrastructural obstructions (dams and bar- } \\
\text { rages) }\end{array}$ & $\begin{array}{l}\text { Exponential reduction of river flow } \\
\text { Seasonal water level depletion } \\
\text { Extreme bank erosion for extreme stress due } \\
\text { to abrupt flow rise } \\
\text { Destruction of the fish habitats } \\
\text { Lowering carp fish egg productions }\end{array}$ & $\begin{array}{l}\text { Relocation of dams and barrages } \\
\text { Planned operations and maintenance is } \\
\text { essential }\end{array}$ \\
\hline $\begin{array}{l}\text { Exploitation in industrial and residential } \\
\text { usage of river water }\end{array}$ & $\begin{array}{l}\text { Contaminating the river with waste dumping } \\
\text { Dropping the water quality for fish survival } \\
\text { Increase in river water temperature due to hot } \\
\text { water discharge } \\
\text { Lowering the PH of the river water with toxic } \\
\text { chemical and wastes } \\
\text { Over-extraction of water by tobacco and tea } \\
\text { cultivation farms } \\
\text { Contamination with use of poultry wastage } \\
\text { as fish food }\end{array}$ & $\begin{array}{l}\text { Introduction of mandatory water treatment } \\
\text { plant by industries } \\
\text { Proper management of drainage and dis- } \\
\text { charge water } \\
\text { Estimated water supply through a pipe } \\
\text { system } \\
\text { Introduction of biodegradable and organic } \\
\text { fish foods }\end{array}$ \\
\hline Short-sighted interventions & $\begin{array}{l}\text { Unplanned dredging and sand mining caus- } \\
\text { ing the mass failure of the banks } \\
\text { Bank erosion severely damages the fish habi- } \\
\text { tats and egg production } \\
\text { Straightening of the river through loop cut- } \\
\text { ting destroys fish habitat }\end{array}$ & $\begin{array}{l}\text { Planned and monitored Sand mining \& } \\
\text { dredging } \\
\text { The manual Sand extraction is sustainable } \\
\text { Protection of the loops and fish breeding } \\
\text { areas }\end{array}$ \\
\hline Climate change impacts and salinity intrusion & $\begin{array}{l}\text { Fish eggs damage due to the increasing salin- } \\
\text { ity intrusion } \\
\text { Climate change will increase the salinity } \\
\text { exponentially due to the backflow of the } \\
\text { river }\end{array}$ & $\begin{array}{l}\text { Maintenance of the river flow above the } \\
\text { threshold }\end{array}$ \\
\hline
\end{tabular}

\section{Results and analysis}

\subsection{River planform analysis}

Planform analysis of the Halda River basin area is done for the years 1984, 2003, 1989, 2010, and 2014. From the satellite image analysis of the Halda Basin area, it has been observed that the number of streams around the river basin is reducing progressively year by year. This planform change is an indication of land deposition and water flow scarcity in the basin area over the last three decades (Fig. 3).

\section{SN Applied Sciences}

\subsection{River stage trend analysis}

Narayanhat, Panchpukuria, Telpari, and Enayethat BWDB stations are located along the Halda River channel of Chittagong City, Bangladesh. The upstream two stations are non-tidal, whereas the downstream two stations are tidal by nature. Charts have been plotted with observed river stage data collected from BWDB for three decades from 1985 to 2014 (Fig. 4).

The mean stage for the four stations is $4.71 \mathrm{~m}, 12.36 \mathrm{~m}$, $2.60 \mathrm{~m}$, and $2.81 \mathrm{~m}$ PWD (Public Works Datum). The 
Fig. 2 Flow chart of the study methodology

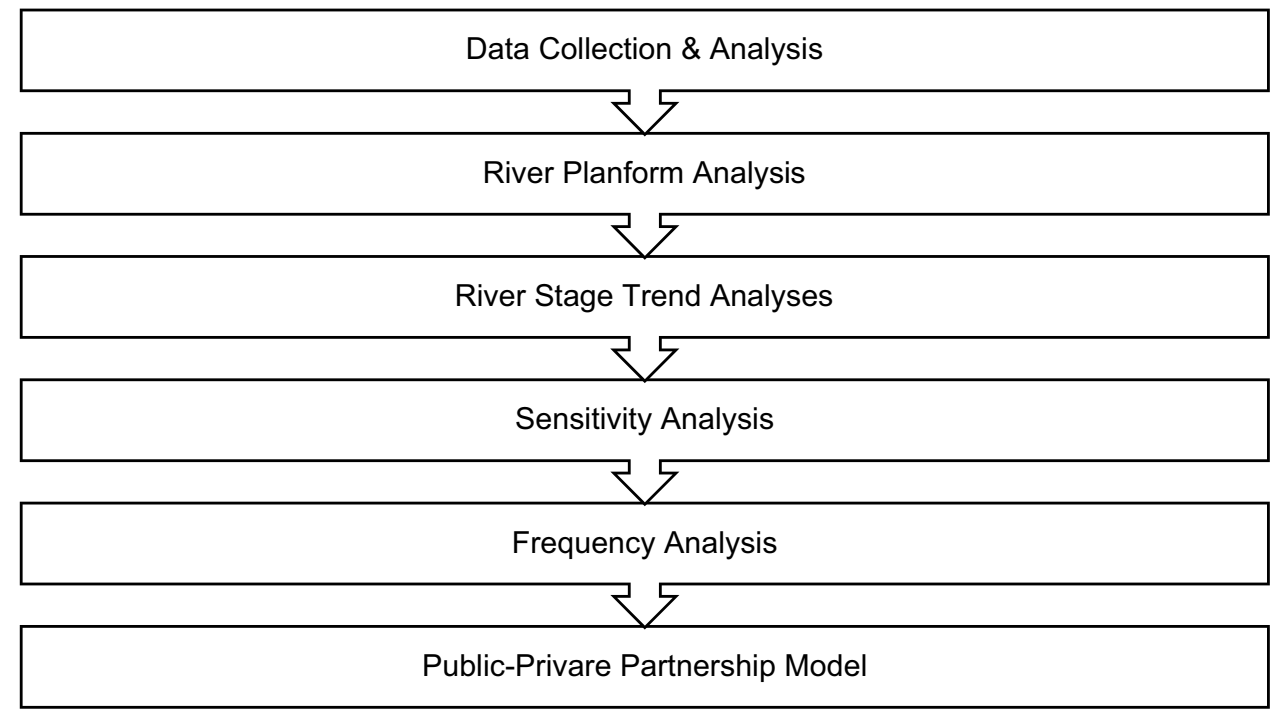

Table 3 Description of the datasets used for analysis

\begin{tabular}{llll}
\hline Data & Source & Extent & Time period \\
\hline Digital elevation model (DEM) & USGS Earth explorer & $\begin{array}{l}\text { Global grid } \\
(30 \mathrm{~m} \times 30 \mathrm{~m})\end{array}$ & 2015 \\
Natural streams of Halda River & Google Earth & Canals connected to river stream & 2017 \\
Historical observations of Halda River & USGS Earth explorer Landsat & $\begin{array}{c}\text { River stream connected to tributary } \\
\text { Canals }\end{array}$ & $\begin{array}{l}1984,1989,2003, \\
2010,2014\end{array}$ \\
River Stage Data & Bangladesh Water Development Board & Narayanhat, Panchpukuria, Telpari, and & $1985-2015$ \\
River Flow Data & Bangladesh Water Development Board & Panchpukuria Station & $1985-2015$ \\
\hline
\end{tabular}

maximum stage in the stations is as high as $19.30 \mathrm{~m}$, $12.54 \mathrm{~m}, 33.40 \mathrm{~m}$, and $5.13 \mathrm{~m}$. The minimum stage in the stations is as low as $2.52 \mathrm{~m}, 11.09 \mathrm{~m}, 0.30 \mathrm{~m}$, and $0.37 \mathrm{~m}$ PWD, showing a radical change at the downstream.

\subsection{Frequency analysis}

\subsubsection{Sensitivity analysis}

The sensitive parameters of the river Halda in the hydrological model (ArcSWAT) analysis [1] were CN (curve number), SOL_AWC (available water capacity of the soil layer), and ESCO (soil evaporation compensation factor). These parameters were selected to calibrate the model for Panchpukuria station in 2014 and validated for the same station in 2012. The confidence interval was $95 \%$ for this sensitivity analysis. Moreover, another sensitivity analysis is performed for the hydrodynamic model (Delft3D) based on the hydrological model outputs with relevance to the river bed roughness (n) of $0.015,0.025,0.035$, and 0.045 . Finally, a roughness of 0.035 was selected on best fit correlations with the Telpari and Narayanhat BWDB Station stage data of April 2014 [1].
The frequency analysis is based on these sensitised flow and stage data of the Halda River.

\subsubsection{Gumbel distribution}

Gumbel distribution [24] is used for the frequency analysis of Panchpukuria Station observed discharge (1985-2015). The peak flow value of the observed discharge is plotted in Fig. 5, which shows a $62 \%$ reduction of flow in the last three decades.

Flow data are organised in descending order, and return period $(T)$ and reduced variate $\left(Y_{t}\right)$ are estimated in Table 4. A return period is an estimated average time between events such as floods, or a river discharge flows to occur. A reduced variate, a procedure that has long been customary in statistics, estimates the differences and variations considering the mean and standard deviations. The equations are of the return period, and reduced variate is as follows [25-27]:

Return Period, $T=\frac{N+1}{M}$ 

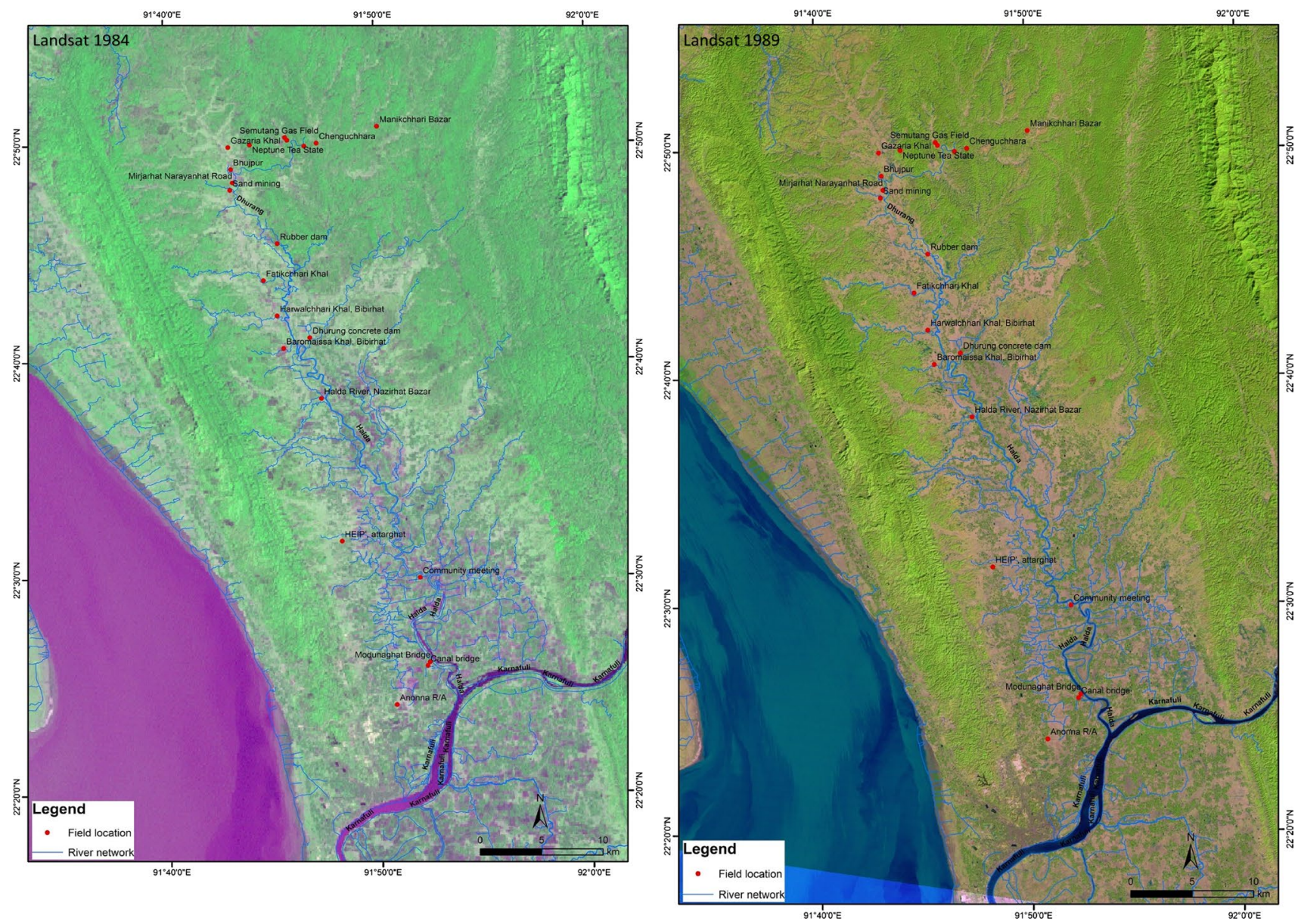

Fig. 3 Landsat images of Halda Basin area (1984, 1989, 2003, 2010, 2014)

Reduced Variate, $Y_{t}=-\ln \left[\ln \left(\frac{T}{T-1}\right)\right]$

where,

$N=$ sample number $=31$,

$M=$ order.

The frequency analysis of flow data determined the return period and reduced variate as high as 32 years and 3.45 , whereas low as 1.03 years and -1.24 for peak flows of $548.67 \mathrm{~m}^{3} / \mathrm{s}$ and $15.01 \mathrm{~m}^{3} / \mathrm{s}$. Peak flow and reduce variate $\left(Y_{t}\right)$ trend analysis correlate $R^{2}=0.98$, which shows that the flow prediction is suitable for the analysis. Peak flow vs reduced variate chart is shown in Fig. 6.

\subsubsection{Estimation of expected flow}

Expected flow for 2-, 5-, 10-, and 15-year return periods is estimated. The frequency factor represents the frequency of the floods, and expected flows are the extreme flows expected over the return periods. Equations used for the analysis with frequency factor and expected flow are as follows [25-27]:

Frequency Factor, $K=\frac{Y_{t}-Y_{n}}{S_{n}}$

where

$Y_{t}=$ reduced variate for expected return period $(T)$,

$Y_{n}=$ reduced mean,

$S_{n}=$ reduced standard deviation,

Expected flow, $X_{T}=\bar{X}+K \times \sigma$

where

$\bar{X}=$ average of peak flow $=211.64$ cumec,

$\sigma=$ standard deviation of the observed peak flow $=147.013$.

From the above-expected flow estimation in Table 5, 2-year, 5-year, 10-year, 15-year return period expected extreme flow results are 189.17 cumec, 338.49 cumec, 437.36 cumec, and 493.13 cumec, respectively. From the flow duration logarithmic curve in Fig. 7, the 75 



Fig. 3 (continued) 

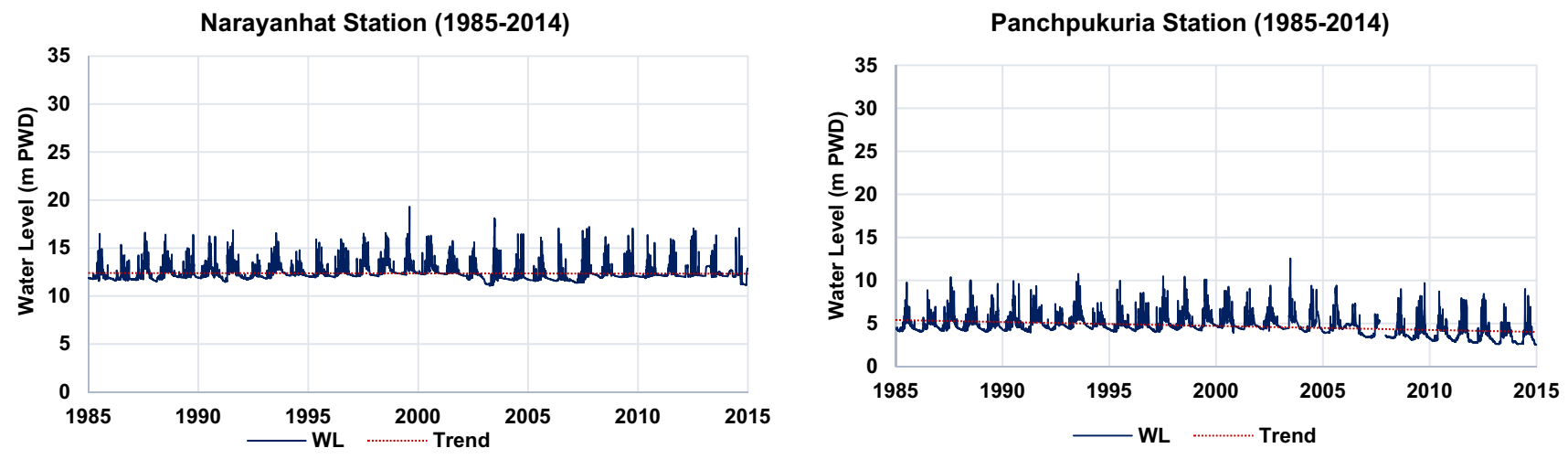

Telpari Station (1985-2014)

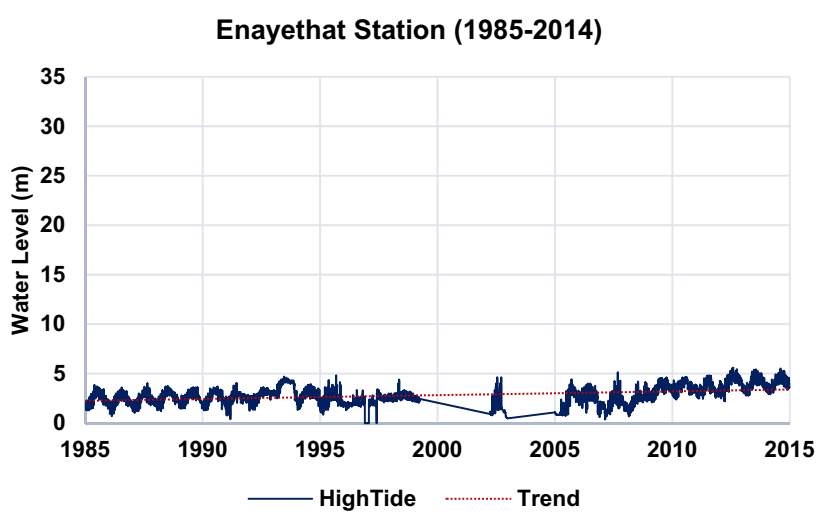

Fig. 4 River stage trend analysis

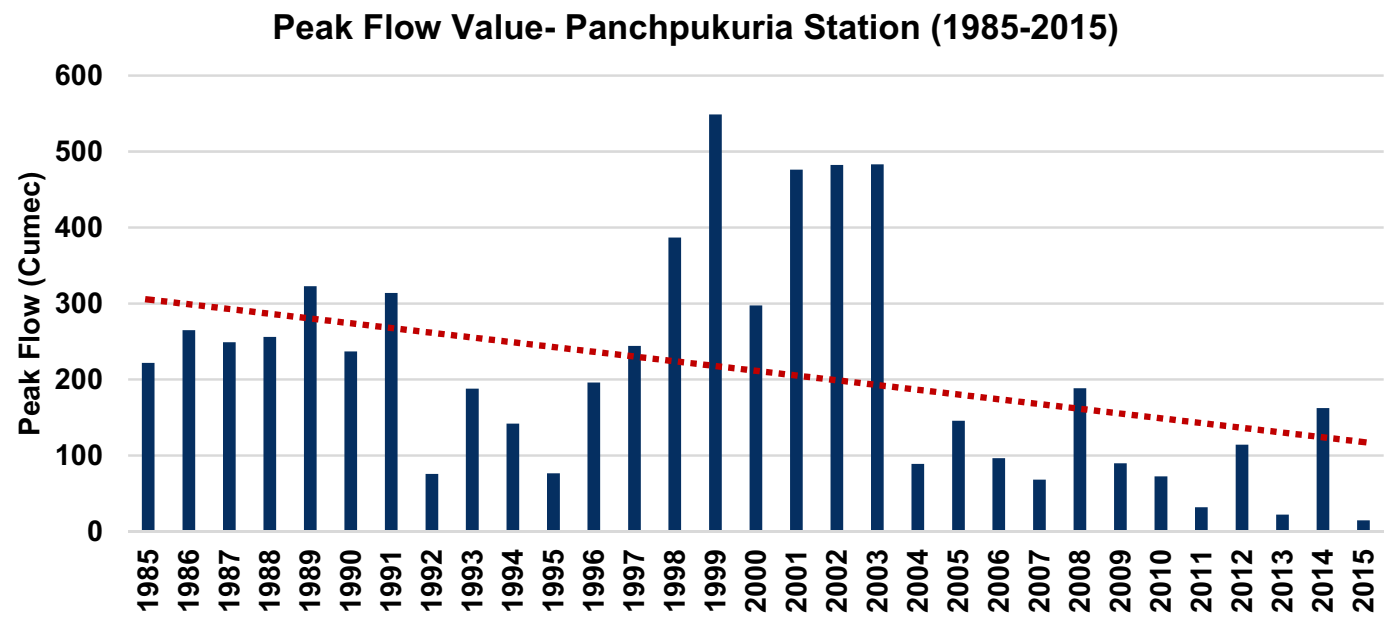

Fig. 5 Peak flow value of Panchpukuria Station (1985-2015) 
Table 4 Frequency analysis and estimation

\begin{tabular}{|c|c|c|c|c|}
\hline Year & Peak flow (cumec) & Order $(M)$ & Return period, $T$ & $\begin{array}{l}\text { Reduced } \\
\text { variate, } Y_{T}\end{array}$ \\
\hline 1999 & 548.67 & 1 & 32.00 & 3.45 \\
\hline 2003 & 483.23 & 2 & 16.00 & 2.74 \\
\hline 2002 & 482.34 & 3 & 10.67 & 2.32 \\
\hline 2001 & 476.23 & 4 & 8.00 & 2.01 \\
\hline 1998 & 386.95 & 5 & 6.40 & 1.77 \\
\hline 1989 & 323.00 & 6 & 5.33 & 1.57 \\
\hline 1991 & 314.00 & 7 & 4.57 & 1.40 \\
\hline 2000 & 297.65 & 8 & 4.00 & 1.25 \\
\hline 1986 & 265.00 & 9 & 3.56 & 1.11 \\
\hline 1988 & 256.00 & 10 & 3.20 & 0.98 \\
\hline 1987 & 249.00 & 11 & 2.91 & 0.86 \\
\hline 1997 & 244.23 & 12 & 2.67 & 0.76 \\
\hline 1990 & 237.00 & 13 & 2.46 & 0.65 \\
\hline 1985 & 222.00 & 14 & 2.29 & 0.55 \\
\hline 1996 & 196.00 & 15 & 2.13 & 0.46 \\
\hline 2008 & 188.41 & 16 & 2.00 & 0.37 \\
\hline 1993 & 188.00 & 17 & 1.88 & 0.28 \\
\hline 2014 & 162.57 & 18 & 1.78 & 0.19 \\
\hline 2005 & 145.74 & 19 & 1.68 & 0.10 \\
\hline 1994 & 141.93 & 20 & 1.60 & 0.02 \\
\hline 2012 & 114.38 & 21 & 1.52 & -0.07 \\
\hline 2006 & 96.75 & 22 & 1.45 & -0.15 \\
\hline 2009 & 89.87 & 23 & 1.39 & -0.24 \\
\hline 2004 & 89.12 & 24 & 1.33 & -0.33 \\
\hline 1995 & 76.70 & 25 & 1.28 & -0.42 \\
\hline 1992 & 75.80 & 26 & 1.23 & -0.52 \\
\hline 2010 & 72.68 & 27 & 1.19 & -0.62 \\
\hline 2007 & 68.30 & 28 & 1.14 & -0.73 \\
\hline 2011 & 32.10 & 29 & 1.10 & -0.86 \\
\hline 2013 & 22.30 & 30 & 1.07 & -1.02 \\
\hline 2015 & 15.01 & 31 & 1.03 & -1.24 \\
\hline
\end{tabular}

Table 5 Estimation of expected extreme flow

\begin{tabular}{llllll}
\hline $\begin{array}{l}\text { Return } \\
\text { period } \\
(T)\end{array}$ & $\begin{array}{l}\text { Reduced } \\
\text { variate }\left(Y_{t}\right)\end{array}$ & $Y_{n}$ & $S_{n}$ & $\begin{array}{l}\text { Frequency } \\
\text { factor }(K)\end{array}$ & $\begin{array}{l}\text { Expected } \\
\text { flow, } X_{T} \\
\text { (cumec) }\end{array}$ \\
\hline 2 & 0.367 & 0.537 & 1.116 & -0.153 & 189.170 \\
5 & 1.500 & 0.537 & 1.116 & 0.863 & 338.492 \\
10 & 2.250 & 0.537 & 1.116 & 1.535 & 437.356 \\
15 & 2.674 & 0.537 & 1.116 & 1.915 & 493.134 \\
\hline
\end{tabular}

percentile flow $\left(Q_{75}\right)$ from 1985-2015 flow data is estimated as $90 \mathrm{~m}^{3} / \mathrm{s}$, showing peak flow for a significant number of years below the required flow.

\subsubsection{Minimum flow analysis of dams}

Charts have been plotted with ten sequential days of minimum flow in three dams for each month over the Halda River to assess the flow scenario in Fig. 8.

\subsection{Public-private partnership}

It is evident from all the trend and frequency analyses that the river flow is dying continuously over time due to different human interventions. The planform analyses also show the encroachment of the river over the last three decades, whereas the trend and frequency analyses show that the water level and flow are decreasing linearly over the years due to continuous human interventions. So, this study proposes a public-private partnership model to tackle the issues of an endangered river and the sustainability of the river. This model proposes and envisages a partnership between the government and the private sector, along with the local community to save the river.

\subsubsection{Stakeholder analysis}

In Bangladesh, National Water Policy (1999) and the National Water Management Plan (2001) are the basis of the responsible stakeholders' identification [28-30]. Hence, the recommendations from the stakeholders and the opinion of national water experts are considered on the identification of water sector stakeholders for Halda River. Based on the modality of work, all stakeholders have been clustered into six broad categories. A list of these responsible stakeholders for the sustainability of the Halda River is represented in Table 6.

\subsubsection{Public-private partnership model}

Public-private partnership takes an extensive variety of forms shifting in the level of risk and involvement engaged to the stakeholder and is generally set out in an agreement to framework the responsibilities of each actor [31, 32]. So based on the major issues, authorities, and benefits, we listed out each responsible stakeholder for the survival of the Halda River in Table 7. The most critical aspect of public-private partnership is to ensure effectiveness and sustainability over time. Considering the sustainability and cooperation among the stakeholders, a standard public-private partnership model is proposed in Fig. 8 (Fig. 9). 
PEAK FLOW VS REDUCED VARIATE CHART

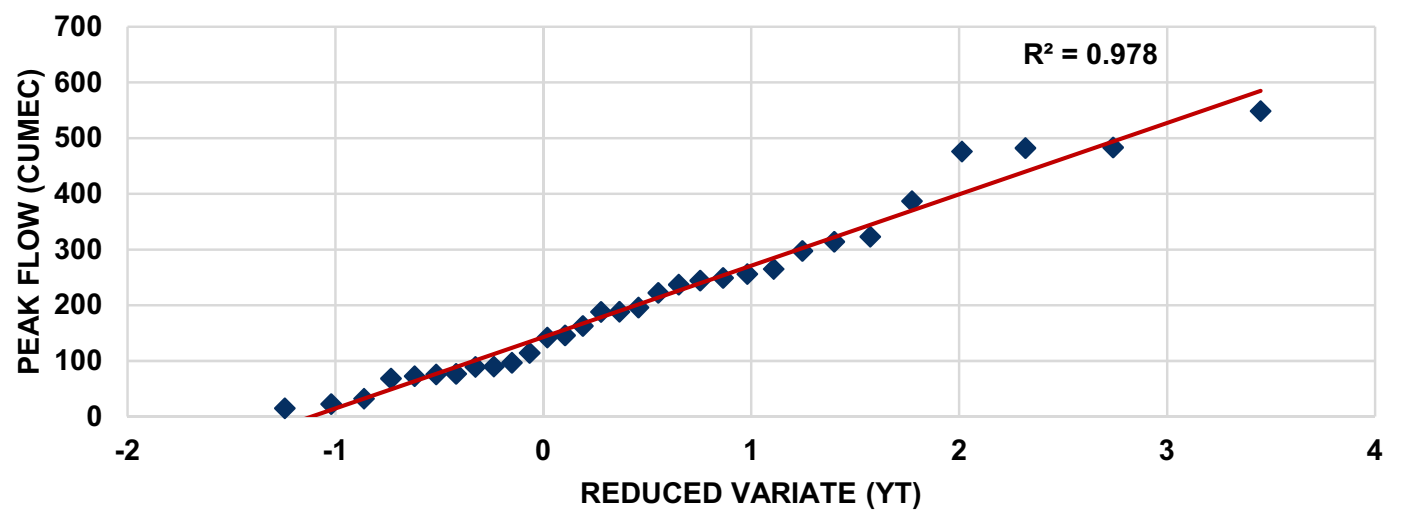

Fig. 6 Peak flow versus reduced variate chart

\section{Flow Duration Curve}

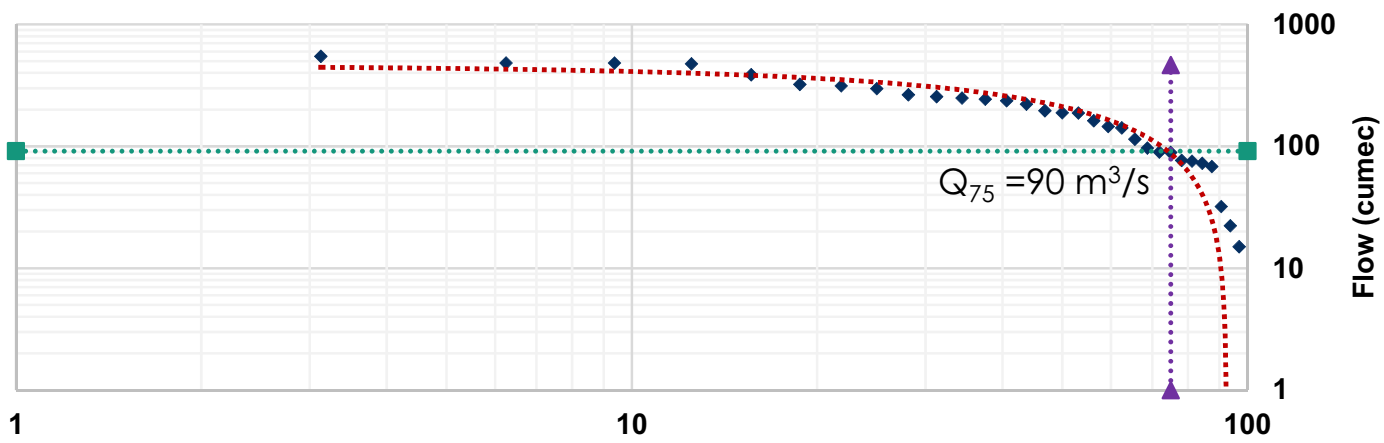

Percentage Time Indicated Discharge is equalled or Exceeded (\%)

Fig. 7 Flow duration curve

\section{Discussion}

In this study, the resolution of the DEM used for the hydrological analysis was $30 \mathrm{~m}$ by $30 \mathrm{~m}$, which was reconditioned by hand delineated stream network of river Halda. In order to have a good delineation for the watershed and the flow analysis, finer resolution DEM may contribute an excellent estimation of the flow and the analysis as well.

The Landsat images (Fig. 2) of Halda Basin from the 1990s (1984 and 1989) show that river streams are in a complex network, and a significant number of streams in the river basin can be identified. Additionally, river flow is continuous throughout the watershed, indicating adequate flow in the rivers. The Landsat image of Halda Basin after 2000 (2003, 2010, and 2014) shows that the river channels are although in a complex network, the number of streams is decreasing progressively over the years. This indicates significant unplanned human interventions over the river flow in the 2000s. From past literature studies [33,
34], it is also evident that the total area of the water body in the Chittagong district decreased by 3\% from 1989 to 2014. Consequently, river flow is interrupted and slowly becoming insufficient in the river reaches for the sustainability of fish spawning. So, the analysis shows that canals and tributary of Halda River have been encroached over the years, and the number of streams is reducing significantly.

River stage trend is in the decreasing order for the last 30 years, and almost $1.26 \mathrm{~m}$ WL has been reduced for Panchpukuria. The stage trend in the river has almost been similar for Narayanhat and Telpari, whereas the trend in Enayethat is in the increasing order. Telpari and Enayethat are the downstream tidal stations of the Halda river, and even on their high tide, the stage is well below the upstream stations of the river, which represents the impacts of the infrastructural obstructions on the flow. In this way, PWD shows an erratic change with the streamwise channel propagation representing the infrastructural 
Bhujpur Rubber Dam Minimum Flow Analysis (2014)

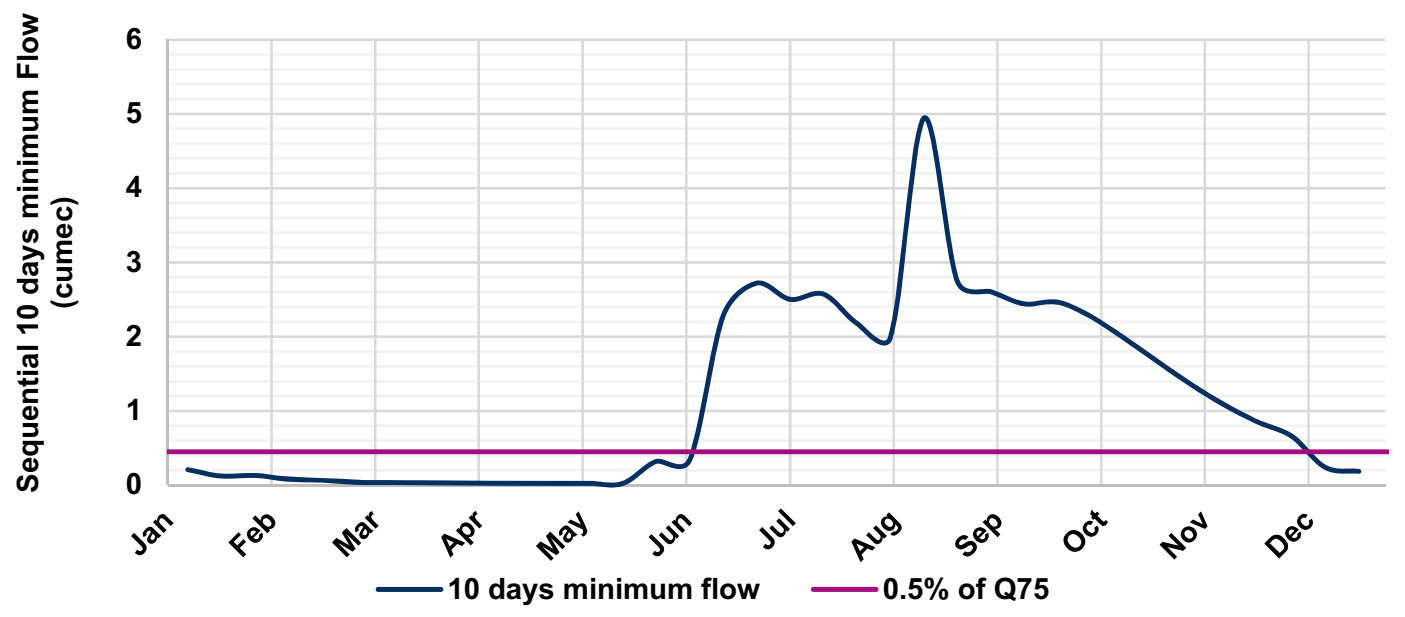

Haruwalchhari Canal Minimum Flow Analysis (2014)

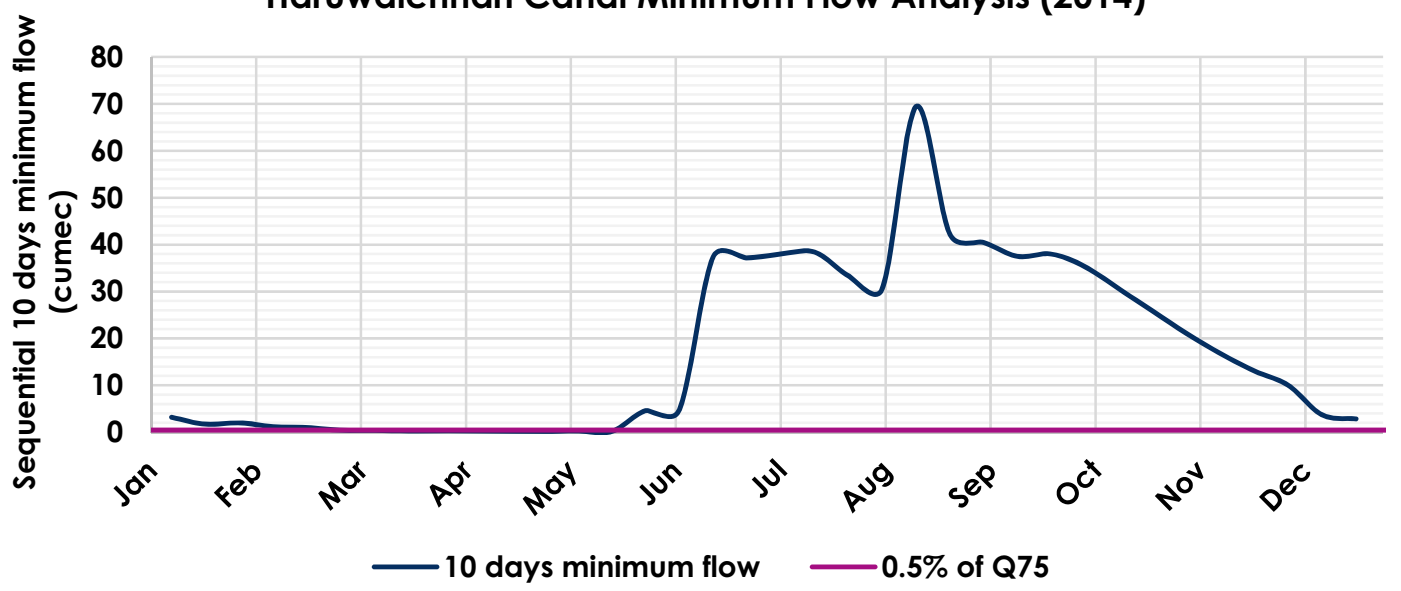

BWDB Irrigation Canal Minimum Flow Analysis (2014)

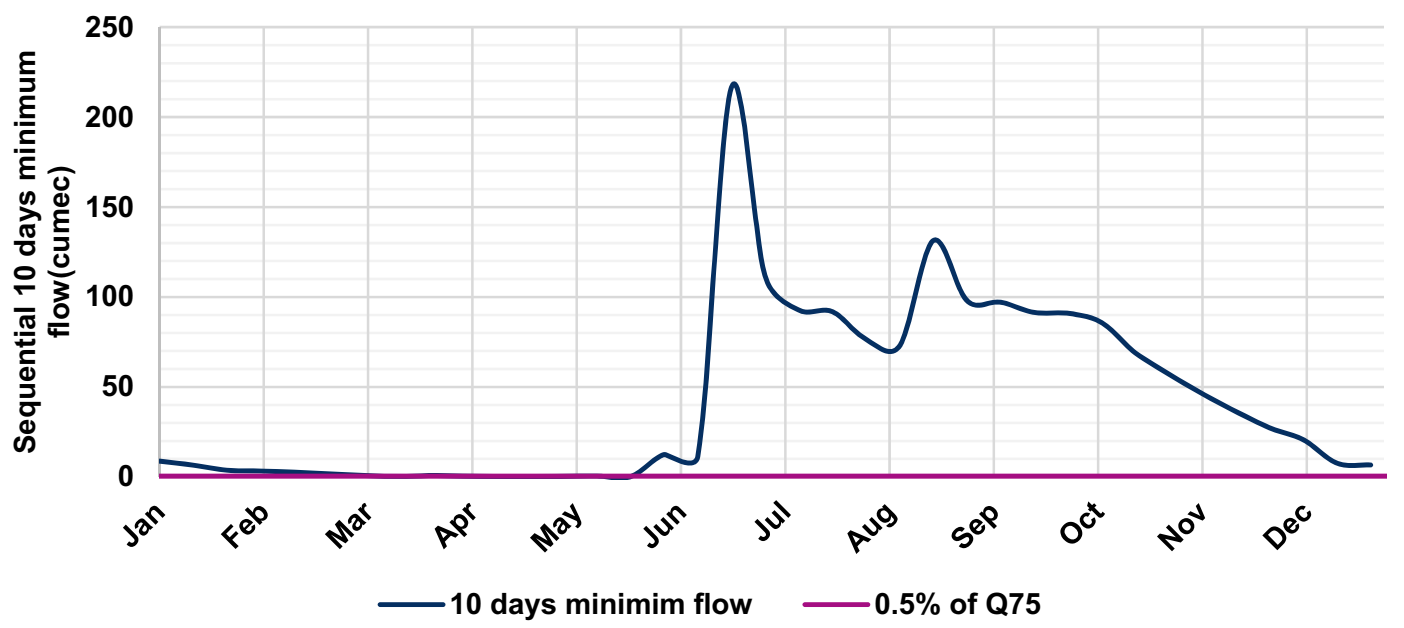

Fig. 8 Minimum flow analysis of dams (2014) 
Table 6 List of responsible stakeholders on Halda River

\begin{tabular}{|c|c|}
\hline Categories of stakeholders & Name of the organisations and institutes \\
\hline & Ministry of Water Resources (MoWR) \\
\hline & Ministry of Agriculture (MoA) \\
\hline & Ministry of Environment and Forest (MoEF) \\
\hline & Water Resources Planning Organization (WARPO) \\
\hline \multirow[t]{5}{*}{ Implementing Organizations } & Bangladesh Water Development Board (BWDB) \\
\hline & Bangladesh Agricultural Development Corporation (BADC) \\
\hline & Local Government Engineering Department (LGED) \\
\hline & Chittagong City Corporation (CCC) \\
\hline & Department of Fisheries (DoF) \\
\hline \multirow[t]{7}{*}{ Academia, Research, and Activist organisation } & Department of Water Resources Engineering (BUET) \\
\hline & Institute of Water and Flood Management (IWFM) \\
\hline & Center for Environmental and Geographic Information Services (CEGIS) \\
\hline & Centre for Climate Change and Environmental Research (C3ER) \\
\hline & Institute of Water Modelling (IWM) \\
\hline & International Union for Conservation of Nature, Bangladesh (IUCN) \\
\hline & River Research Institute (RRI) \\
\hline \multirow[t]{7}{*}{ Donor organization } & Asian Development Bank (ADB) \\
\hline & World Bank (WB) \\
\hline & Japan International Cooperation Agency (JICA) \\
\hline & Embassy of the Kingdom of the Netherlands (EKN) \\
\hline & United Nations Development Programme (UNDP) \\
\hline & United States Agency for International Development (USAID) \\
\hline & UN Food and Agriculture Organization (FAO) \\
\hline \multirow[t]{6}{*}{ Local CSOs, CBOs, NGOs, and INGOs organisation } & BRAC \\
\hline & WaterAid Bangladesh (WAB) \\
\hline & ActionAid Bangladesh \\
\hline & WorldFish Bangladesh \\
\hline & Practical Action Bangladesh \\
\hline & Christian Commission for Development (CCDB) \\
\hline
\end{tabular}

Table 7 Responsible stakeholders and their benefits

\begin{tabular}{|c|c|c|}
\hline Problems & Responsible stakeholders & Benefits \\
\hline $\begin{array}{l}\text { Infrastructural Obstructions (dams and bar- } \\
\text { rages) }\end{array}$ & BWDB, Chittagong CC, LGED, Fisheries Dept & $\begin{array}{l}\text { Relocate, repair, and maintenance of the } \\
\text { hydraulic infrastructures }\end{array}$ \\
\hline $\begin{array}{l}\text { Exploitation in industrial and residential } \\
\text { usage of river water }\end{array}$ & $\begin{array}{l}\text { Tobacco and tannery industries (TTI)(TTI), } \\
\text { Brick Fields (BF), Chittagong CC, (LGED), Tea } \\
\text { estates, BADC, BWDB }\end{array}$ & $\begin{array}{l}\text { Protection of the river from pollution, } \\
\text { extraction of clean water, increase in fish } \\
\text { resources, optimal temperature for fish } \\
\text { survival and ensuring steady supply to all } \\
\text { sectors to maintain river flow }\end{array}$ \\
\hline Short-sighted interventions & $\begin{array}{l}\text { BWDB, Chittagong CC, LGED, Department of } \\
\text { Fisheries }\end{array}$ & $\begin{array}{l}\text { The increase in river flow, sand mining, sur- } \\
\text { vival of fish resources, protection of the fish } \\
\text { breeding areas, increase in fish resources, } \\
\text { and eggs in Halda }\end{array}$ \\
\hline Climate change impacts and salinity intrusion & $\begin{array}{l}\text { BADC, BWDB, Chittagong CC, Department of } \\
\text { Fisheries }\end{array}$ & $\begin{array}{l}\text { Protection from salinity, maintain river flow } \\
\text { and adaptation from potential climate } \\
\text { change impacts }\end{array}$ \\
\hline
\end{tabular}




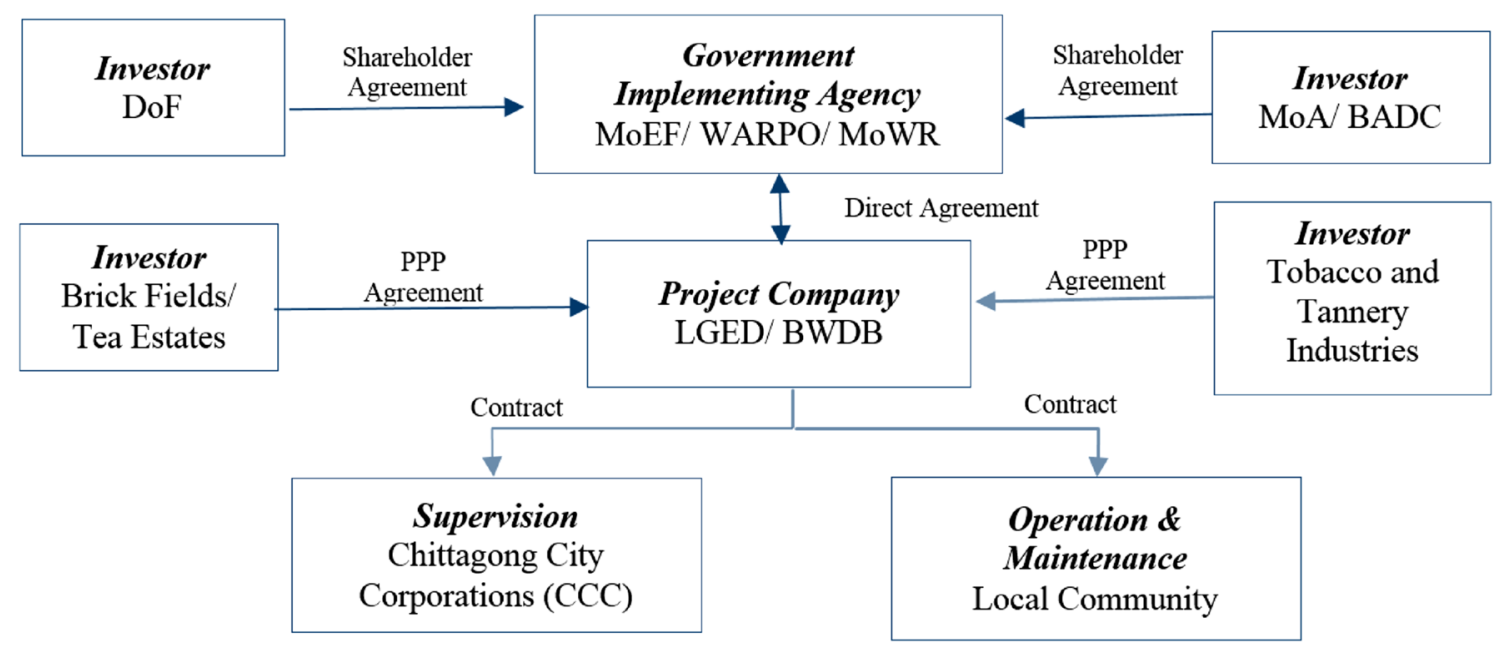

Fig. 9 Proposed PPP model for sustainable Halda River

obstruction impacts. Hydrodynamic modelling of Halda River [1] also showed the same erratic changes in the river water level, specifically during the pre-monsoon period.

From the sensitivity analysis, the curve number, available soil water capacity, and the soil evaporation compensation factor are found to be the sensitive parameter. These parameters were identified as sensitive while calibrating the discharge for the year 2014. In a past research article [35], this finding was different from the current finding. In that article, the calibration was done for the 1998-2004 discharge data of Panchpukuria Station. The comparison between the studies shows that the sensitivity parameters of the river Halda have changed over the decade.

Following the sensitivity analysis, a frequency analysis was performed using 30 years (1985-2015) of river discharge data. The peak flow value of the observed discharge shows a $62 \%$ reduction of flow in the last three decades. From frequency analysis, return period and reduced variate are estimated for the peak flows of the period 1985-2015. The expected extreme flows estimated for 2-year, 5-year, 10-year, 15-year return periods are 189.17 cumec, 338.49 cumec, 437.36 cumec, and 493.13 cumec, respectively. According to Water Quality Accountability Act (WQAA) requirement for good ecological condition flow for fish habitat, 10 sequential days of minimum flow should be above $0.5 \%$ of the $Q_{75}$ flow of the river [36]. Using the flow duration curve, the 75 percentile value was estimated. The estimated value for $Q_{75}$ is 90 cumec [37]. The minimum required flow $(0.5 \%$ of $Q 75)$ for fish habitat survival is estimated at 0.45 cumec. Form the chart (Fig. 8) of the Bhujpur rubber dam, minimum flow for ten sequential days from December to May is below $0.5 \%$ of the $Q_{75}$ flow requirement. Form the chart (Fig. 8) of the Haruwalchhari rubber dam and Irrigation Canal Dam, minimum flow of ten sequential days from March to May is equal to $0.5 \% Q_{75}$ flow requirement. So, the flow in these dams is below the threshold flow requirement and is endangering the ecological sustainability required for the survival of fish habitat and spawning, especially from March to May. The minimum flow analysis clearly states the extreme degradation in the Halda River for the ecological sustainability required for the survival of fish habitat and spawning. Building block analysis from a previous study [1] also showed a similar critical condition of Halda River.

Following the need for public and private engagement to restore the endangered river as well as its aquatic life, a public-private partnership model has been proposed in this study. Stakeholder analysis has been performed to generate the public-private partnership model, which will be further investigated through consultations. According to this model, stakeholders, government, project companies, and investors must come to an agreement in terms of saving the endangered natural stream and its aquatic life from extinction.

The limitations of the study were the short-term analysis of the public-private partnership, and to implement practically, the study proposes a pilot project of PPP on a small site of Halda River. Looking forward, the study also proposes a benthic and ecological assessment of the river to ensure the protection of Halda's vast aquatic and ecological habitat.

\section{Conclusion}

Halda River, being the one and the only natural carp breeding ground, is one of the most economically important rivers in Bangladesh. So, a sustainability analysis is 
conducted based on river planform analysis, stage trend analysis, and frequency analysis to address the issues of Halda River. The planform analysis shows that canals and tributary of Halda Rivers have been encroached over the years, and the number of streams is reducing significantly. Consequently, the river flow is becoming insufficient for the sustainable survival of the fish spawning. The trend analysis shows that the river stage is in the decreasing order for the last three decades. The minimum stage in the four locations is recorded as low as $2.52 \mathrm{~m}, 11.09 \mathrm{~m}, 0.30 \mathrm{~m}$, and $0.37 \mathrm{~m}$ PWD, showing a radical change at the downstream, which represents the extensive impacts of the infrastructural obstructions over the flow. Sensitivity analysis was conducted, and a $95 \%$ confidence interval was found for the ArcSWAT model in comparison with 2012 and 2014 Panchpukuria Station flow data [1]. Frequency analysis is conducted based on Gumbel distribution, and expected extreme flows estimated for 2-year, 5-year, 10-year, 15-year return periods are 189.17 cumecs, 338.49 cumecs, 437.36 cumecs, and 493.13 cumec, respectively. The estimated value for $Q_{75}$ is 90 cumec, and the minimum required flow requirement $(0.5 \%$ of $Q 75)$ for fish habitat survival is estimated at 0.45 Cumec. From the minimum flow analysis for Bhujpur, Haruwalchhari, and BWDB irrigation canal, the flow in these dams is below the threshold flow requirement and is endangering the ecological sustainability of fish habitat and spawning especially from March to May.

To address the issues and save the Halda River, a joint effort from the government and the private organisation has become essential. So to solve the issues, a number of key stakeholders have been listed out, who has jurisdiction and responsibility for Halda River. To ensure successful cooperation, a public-private partnership model is proposed for the Halda River, incorporating the responsibilities of each party. This model envisages a partnership between the government and the private sector, along with the local community for the sustainable survival of the river. To solve the major issues, the government ministries like water, agriculture, fisheries, and the environment must work together for the survival of the river. Also, local institutes like tobacco and tannery industries, brickfields, tea estates, Chittagong city corporations, and local community must be partnered to support them in the survival of Halda River. The most critical aspect of public-private partnership is to ensure effectiveness and sustainability over time. Working together through the PPP model, each of the stakeholders will find future economic and sustainability benefits. Considering all these, a public-private partnership model can be envisioned instrumental for the survival of the Halda River.
Acknowledgements The study of the Halda River leading to these results has received a grant from the United Nations Development Programme, Bangladesh UNDP-BD/CPS/2017, under Grant Agreement No. 011 (Conduct three feasibility studies on Halda River).

\section{Compliance with ethical standards}

Conflict of interest On behalf of all authors, the corresponding author states that there is no conflict of interest.

\section{References}

1. Saha P, Islam M, Oyshi JT, Khanum R, Nishat A (2019) A sustainability study of the flow regulation impacts by dams in a carp breeding river using the hydrodynamic model and building block analysis. SN Appl Sci 1:1429

2. Azadi MA, Alam MA (2013) Ichthyofauna of the River Halda, Chittagong, Bangladesh. Bangladesh J Zool 41(2):113-133

3. MoFL (2016) Impact Assessment on Upstream Water Withdrawal to Conserve Natural Breeding Habitat of Major Carps in the River Halda, Department of Water Resources Engineering, Ministry of Fisheries And Livestock, Dhaka

4. Kabir H, Kibria M, Jashimuddin M, Hossain MM (2015) Conservation of a river for biodiversity and ecosystem services the case of the Halda the unique river of Chittagong Bangladesh. Int J River Basin Manag 13(3):333-342

5. Ali R, Kuriqi A, Abubaker SR, Kisi O (2019) Hydrologic alteration at the upper and middle part of the Yangtze River, China: towards sustainable water resource management under increasing water exploitation. Sustainability 11:19

6. Kuriqi A, Kocileri G, Ardiclioglu M (2019) Potential of MeyerPeter and Müller approach for estimation of bed-load sediment transport under different hydraulic regimes. Model Earth Syst Environ 5(10):1-9

7. Kuriqi A, Pinheiro AN, Sordo-Ward A, Garrote L (2019) Influence of hydrologically based environmental flow methods on flow alteration and energy production in a run-of-river hydropower plant. J Clean Prod 232:1028-1042

8. Akhter A, Ali MH (2012) Environmental flow requirements assessment in the Halda River, Bangladesh. Hydrol Sci J 57(2):326-343

9. Ronald PW, Azadi MA (1985) Hydrological conditions influencing the spawning of major carps in the Halda river, Chittagong, Bangladesh. Bangladesh J Zool 13(1):63-72

10. Rahman $S$, Islam AKMS, Saha P, Tazkia AR, Krien $Y$, Durand F, Testut L, Islam GMT, Bala SK (2019) Projected changes of inundation of cyclonic storms in the Ganges-BrahmaputraMeghna delta of Bangladesh due to SLR by 2100. J Earth Syst Sci Springer 128:145

11. Rahman S, Rahman MA (2015) Climate extremes and challenges to infrastructure development in coastal cities in Bangladesh. Weather Clim Extrem Elsevier 7:96-108

12. The New Nation (2009) High salinity in Karnaphuli water hinders

13. Zaman F (2014) River Halda awakening: a research training and awareness. BRAC University, Dhaka, Department of Architecture

14. Ardiclioglu M, Kuriqi A (2019) Calibration of channel roughness in intermittent rivers using HEC-RAS model: case of Sarimsakli creek, Turkey. SN Appl Sci 1:1080

15. Yan M, Chi H, Yang J, Chien K (2019) Towards a city-based cultural ecosystem service innovation framework as improved 
public-private-partnership model-a case study of Kaohsiung Dome. J Open Innov Technol Market Complex 5:85

16. Rong Z, Yalong J (2018) The Evaluation of PPP mode of environmental pollution prevention and control based on the view of the perspective of sustainable development. In: IOP conference series: earth and environmental science

17. Klijn E-H, Teisman GR (2003) Institutional and strategic barriers to public-private partnership: an analysis of dutch cases. Publ Money Manag 23:3

18. Burke R, Demirag I (2019) Risk transfer and stakeholder relationships in Public-Private Partnerships. Account Forum, vol 41, no 1. Public Sector Reforms, Public Private Partnerships, and Whole of Government Accounting

19. Bennett E, Grohmann P, Gentry B (1999) Public-private partnerships for the urban environment options and issues. UN Dev Program, New York

20. Meier F, Schöffski O, Schmidtke J (2013) Public-private partnership as a solution for integrating genetic services into health care of countries with low and middle incomes. J Commun Genet Springer 4(3):309-320

21. Massoud M, El-Fadel M (2002) Public-private partnerships for solid waste management services. Environ Manag Springer 30(5):621-630

22. Saha P, Ashraf A, Tasneem J, Chakraborty M (2018) River assessment and water management strategy in South-West coastal region of Bangladesh. Int J Manag Appl Sci 4:2

23. Bhan M (2013) The role of public private partnerships in U.S. environmental policy: case of the EPA and the U.S. Semiconductor industry. Publ Purp 11:49

24. Gumbel E (1935) Les valeurs extrêmes des distributions statistiques. Ann Inst Henri Poincaré 5(2):115-158

25. Bhagat $N$ (2017) Flood frequency analysis using gumbel's distribution method: a case study of lower Mahi Basin, India. J Water Resour Ocean Sci 6(4):51-54

26. Maity R (2018) Frequency analysis, risk, and uncertainty in hydroclimatic analysis. In: Statistical methods in hydrology and hydroclimatology, Springer, Singapore, Springer Transactions in Civil and Environmental Engineering, pp 145-189
27. Maity R (2018) Statistical methods in hydrology and hydroclimatology. In: Springer Transactions in Civil and Environmental Engineering. Springer, Singapore

28. MoWR (1999) National Water Policy, Ministry of Water Resources, Government of the People's Republic of Bangladesh, Dhaka

29. MoWR (2001) National Water Management Plan, Ministry of Water Resources, Government of the People's Republic of Bangladesh, Dhaka

30. Mirza MMQ, Mandal UK, Rabbani MG, Nishat A (2019) Integration of national policies towards addressing the challenges of impacts of climate change in the GBM region. In: The Sundarbans: a disaster-prone eco-region, vol 30. Springer, Coastal Research Library, pp 581-607

31. Murekezi P, Menezes A, Ridler N (2018) Contract farming and public-private partnerships in aquaculture: lessons learned from East African countries. Food Agric Org UN, Rome

32. Zhu J, Huang W, Sun W, Huang G (2016) Waste management model associated with public-private partnership in Hamilton, Ontario, Canada. J Environ Eng ASCE 142:3

33. Rai R, Zhang Y, Paudel B, Li S, Khanal NR (2017) A synthesis of studies on land use and land cover dynamics during 1930-2015 in Bangladesh. Sustainability 9(10):1866

34. Roy B, Saha P (2016) Temporal analysis of land use pattern changes in chittagong district of Bangladesh using Google Earth and ArcGIS. In: Annual Int'I Conference on Chemical Processes, Ecology \& Environmental Engineering (ICCPEE'16), Pattaya (Thailand)

35. Raihan F, Beaumont LJ, Marina J, Islam A, Harrison S (2019) Simulating streamflow in the Upper Halda Basin of southern Bangladesh using SWAT model. Hydrol Sci J

36. WQAA (2007) Minimum flows in the rivers, Central Water Commission, Ministry of Water Resources, Govt. of India, New Delhi

37. Subramanya K (2008) Engineering hydrology. Tata McGraw-Hill Publishing Company Limited, New Delhi, p 163

Publisher's Note Springer Nature remains neutral with regard to jurisdictional claims in published maps and institutional affiliations. 